\title{
Concentration in the Turkish Cement Industry
}

\author{
Gürkan Çalmaşur $^{1} \&$ Hüseyin Daştan ${ }^{1}$ \\ ${ }^{1}$ Faculty of Economics and Administrative Sciences, Erzurum Technical University, Erzurum, Turkey \\ Correspondence: Gürkan Çalmaşur, Faculty of Economics and Administrative Sciences, Erzurum Technical \\ University, Erzurum, Turkey. Tel: 444-5388. E-mail: gurkan.calmasur@erzurum.edu.tr
}

Received: July 1, 2015 Accepted: August 17, 2015 Online Published: September 21, 2015

doi:10.5539/ass.v11n26p142 URL: http://dx.doi.org/10.5539/ass.v11n26p142

\begin{abstract}
The market structure of the industry can be analyzed by reference to various indicators. These indicators are small or large firms operating in industry, market share, technological structure and competitive conditions. Todays is valid conditions of imperfect competition, concentration is one of the important indicators that determine whether they have a competitive structure operates. The main objective of this study is to analyze the market structure of the Turkish Cement Industry for the period of 2010-2014. To achieve this goal, domestic, foreign and net sales of firms data used in the study, N-Firm Concentration Ratio, Herfindahl-Hirschman and Entropy Index methods applied separately for each period, using the data set related to the domestic, foreign and net sales of firms in the industry. Consequently, the industry was determined as an oligopoly according to CR4 and CR8 while it was in a competitive market structure according to Herfindahl-Hirschman Index and Entropy Index.
\end{abstract}

Keywords: Turkish cement industry, concentration, n-firm concentration ratio, herfindahl-hirschman index, entropy index

\section{Introduction}

In consequence of value-added in Turkish economy, contributions of employment and exportation, cement industry is in the important sector position. Within industry sub-sector, cement industry is a significant sector which contributes to GDP (Gross Domestic Product).

Practical studies on industrial economics show that concentration becomes gradually an important indicator. Theoretically, a competitive firm equalizes the goods and service price to differential cost. For effective distribution of resources, the most important requirement is being equalize differential cost to the price. But, division is of output in oligopolistic market structures seen imperfect competition is not efficient because the prices exceed the differential cost (Hall, 1988, p. 921).

Economic theory shows that competition will increase with industrial firm, as well. While monopoly market consists of a single firm, perfect competition or monopolistic competition markets consist of many firms. Oligopoly market is made up of a few firms. Number of firms in industry is essential for to figure out the concentration ratio in perfect competition and monopolistic markets which have two, three organization types. Additionally, if a few firms are active, market shares represent the ratio of concentration. Hypothetically, there are two industries consisting of five firms. For example, five firms of first industry have equal market share $(20 \%)$. Comes to second industry, one firm has $80 \%$ market share and the others have $5 \%$. Pricing and the other firm's acts will be absolutely different from each other. Because of the market share differences, it is necessary to calculate heedfully concentration rate (Waldman \& Jensen, 2001, p. 95).

As regards to studies of Mason (1939) and Bain (1949), concentration is one of the most important factors in industrial economy which determines the market structure. So, it is vital to evaluate concentration and reveal determinants of concentration for gain a clear understanding of practical studies on industrial economy. In this context, concentration can be defined as keeping under control the property or checking economic resources or activities by limited units among a small rate of the units having participated activities of economic or the units having participated (Bain, 1959). By means of this notion, it can be possible to research about numbers of firms which are active on economy or industry and their checking powers (Akay, 2007, p. 4).

Concentration shows us that production of goods or service is limited by some big company. Limited firms and their differences of capacious show us that it exists as a low competitive and more concentrated market. 
Concentration can be evaluated as a function of all active firms in the market or market shares of some firms $(\mathrm{Su}$, 2003, p. 17).

Concentration indicators have an importance in a lot of ways. By means of concentration which is fundamental factor to determine the market, it can be possible to have information about numbers of active firms in the industry and their checking power.

Primary purpose of this study is to analyze the market structure of Turkish cement industry in detail for 2010-2014 years period. In this regard, concentration ratio of active firms on Turkish cement industry has been revealed utilizing N-firm concentration ratio, Herfindahl-Hirschman Index and Entropy Index.

This study consists of six chapters. In chapter two, economic capacious of Turkish cement industry, in chapter three, index used for to evaluate concentration, in chapter four, summary of literature and data, in chapter five, empirical evidences, last chapter six, research results are mentioned.

\section{Economic Status of Turkish Cement Industry}

The First cement factory in the world was founded in 1848 in England. In Turkey, however, Darıca Production Plant owned by Arslan Ottoman Incorporated Company and Eskihisar Production Plant owned by Eskihisar Portland Cement and Water Lime Ottoman Incorporated Company were put into operation in 1912. In the same years, 60.000 tons of hydraulic lime was produced in Turkey and, until 1930-1931, hydraulic lime production was above cement production. Those production plants, which met the need for cement of the country, entered into a destructive and backbreaking domestic market competition with each other until 1920, when large quantities were imported. In that period, cement prices fell considerably on the grounds of lack of state intervention to the cement sector. As a result, those two production plants could not resist to the backbreaking competition any more and merged in 1920 under the name Arslan and Eskihisar Müttehit Cement Incorporated Company to act together against cement importation.

At the present time, approximately 71 million tons cement and 63 million tons clinker are produced by 66 production plants with 11335 employees, above 7 million tons cement and above 2 million tons clinker are totally exported.

In Table 1, it can be seen Turkish cement industry's domestic sales by regions.

Table 1. 2010-2014 Turkish Cement Industry's Domestic Sales by Regions (ton)

\begin{tabular}{crcccc}
\hline Regions/Years & $\mathbf{2 0 1 0}$ & $\mathbf{2 0 1 1}$ & $\mathbf{2 0 1 2}$ & $\mathbf{2 0 1 3}$ & $\mathbf{2 0 1 4}$ \\
\hline Mediterranean & 6.731 .415 & 8.122 .096 & 8.523 .916 & 11.232 .760 & 11.408 .933 \\
Eastern Anatolia & 3.362 .483 & 3.335 .885 & 4.760 .517 & 5.211 .903 & 4.991 .903 \\
Aegean & 4.090 .348 & 4.685 .980 & 4.862 .318 & 5.185 .188 & 4.848 .188 \\
South East Anatolia & 4.391 .179 & 4.851 .230 & 5.519 .158 & 5.866 .463 & 6.054 .763 \\
Central Anatolia & 9.518 .872 & 9.851 .677 & 9.898 .265 & 10.723 .033 & 10.531 .092 \\
Black Sea & 7.018 .898 & 7.952 .626 & 7.798 .176 & 8.635 .166 & 9.279 .124 \\
Marmara & 12.606 .805 & 13.451 .386 & 12.567 .842 & 14.085 .891 & 16.061 .927 \\
Total & 47.720 .000 & 52.250 .880 & 53.930 .192 & 60.940 .404 & 63.175 .930 \\
\hline
\end{tabular}

Source: www.tcma.org.tr

When Table 1 is analyzed, it is observed that Turkish cement industry's domestic sales increased consistently in 2010-2014. By the year 2014 the biggest domestic sale occurred in region Marmara and following regions are respectively Mediterranean, Central Anatolia, Black Sea, Southeastern Anatolia, Eastern Anatolia and Aegean.

In table 2, for 2014 it can be seen Turkish cement industry's cement and clinker export by countries. As seen from the table, when Libya is placed on the top of cement export, Egypt is placed on the top of clinker. 
Table 2. 2014 Cement and Clinker Export (ton)

\begin{tabular}{lrlr}
\hline \multicolumn{1}{c}{ Country } & Çement & Country & Clinker \\
\hline Libya & 1.902 .640 & Egypt & 632.360 \\
Syria & 1.068 .034 & Ghana & 372.214 \\
Iraq & 801.652 & Brazil & 281.905 \\
Israel & 677.972 & Mauritania & 214.925 \\
Russia & 592.008 & Dominica & 126.525 \\
Equatorial Guinea & 293.276 & T.R.N.C. & 112.305 \\
Cameroon & 251.933 & Gabon & 105.150 \\
Total & 7.652 .557 & Total & 2.857 .840 \\
\hline
\end{tabular}

www.tcma.org.tr

In Table 3, it can be seen that Turkish cement industry's employment by region. By the period of 2010-2014, region Marmara is placed on the top of the employment and Eastern Anatolia is the last one. Between the years being talked about, employment increased nearly $12.5 \%$.

Table 3. 2010-2014 Turkish Cement Industry's Employment by Region

\begin{tabular}{lccccc}
\hline \multicolumn{1}{c}{ Regions/Years } & $\mathbf{2 0 1 0}$ & $\mathbf{2 0 1 1}$ & $\mathbf{2 0 1 2}$ & $\mathbf{2 0 1 3}$ & $\mathbf{2 0 1 4}$ \\
\hline Mediterranean & 1802 & 1818 & 1847 & 2277 & 2256 \\
Eastern Anatolia & 866 & 835 & 1072 & 1032 & 1004 \\
Aegean & 1176 & 1155 & 1138 & 1127 & 1124 \\
South East Anatolia & 1397 & 1193 & 1265 & 1253 & 1255 \\
Central Anatolia & 1522 & 1507 & 1471 & 1455 & 1472 \\
Black Sea & 1304 & 1340 & 1414 & 1523 & 1698 \\
Marmara & 2007 & 2070 & 2118 & 2058 & 2526 \\
Total & 10074 & 9918 & 10325 & 10725 & 11335 \\
\hline
\end{tabular}

Source: www.tcma.org.tr

In Table 4, it can be seen Turkish cement industry production capacity in 2014 and rate of capacity utilization by regions. As seen from the table region Marmara is placed on the top of capacity of clinker and cement. Rate of capacity utilization in clinker and cement are maximum in Black Sea.

Table 4. 2014 Turkish Cement Industry's Production Capacity and Rate of Capacity Utilization

\begin{tabular}{lcccc}
\hline \multicolumn{1}{c}{ Region } & $\begin{array}{c}\text { Clinker } \\
\text { Capacity }\end{array}$ & $\begin{array}{c}\text { Cement } \\
\text { Capacity }\end{array}$ & $\begin{array}{c}\text { Clinker } \\
\text { Rate of Capacity } \\
\text { Utilization }\end{array}$ & $\begin{array}{c}\text { Cement } \\
\text { Rate of Capacity } \\
\text { Utilization }\end{array}$ \\
\hline Mediterranean & 16.688 .100 & 26.499 .668 & 92,64 & 61,02 \\
Eastern Anatolia & 4.960 .560 & 10.221 .921 & 82,90 & 48,97 \\
Aegean & 5.816 .250 & 9.599 .953 & 92,90 & 60,16 \\
South East Anatolia & 6.228 .950 & 10.538 .313 & 87,69 & 64,57 \\
Central Anatolia & 10.062 .690 & 15.657 .027 & 86,69 & 67,38 \\
Black Sea & 7.513 .440 & 13.509 .149 & 101,35 & 71,97 \\
Marmara & 18.333 .950 & 27.454 .141 & 95,27 & 67,62 \\
Total & 69.603 .940 & 113.480 .171 & 92,22 & 63,90 \\
\hline
\end{tabular}

Source: www.tcma.org.tr 


\section{Concentration Index}

In this chapter, it is examined concentration Index using for determiner market structures of Turkish cement industry.

Concentration rate of an industry are used for an indicator relative strengths of the firms. It is benefited from different indicator for evaluate concentration rate. Fundamental indicators are; Concentration ratio, Herfindahl-Hirschman Index, Entropy Index, Linda Index, Hannah and Kay Index, Hall-Tideman Index, Lorenz Curve and Gini Coefficient, Net Profit Index, Lerner Index, Logarithmic Variance of firm quantities, relative average deviation, Nos Cut Point, Pietra ratio, Condensation ratio etc. It will be dwelled on first three methods of calculation above mentioned.

\subsection{N-Firm Concentration Ratio}

N-Firm concentration ratio is the oldest and commonly used index known among the concentration criterions. In prospect of ith firm's market share is $P_{i}$ concentration ratio is as follows (Curry \& George, 1983, p. 207).

$$
C R_{N}=\sum_{i=1}^{N} P_{i}
$$

$\mathrm{N}$ value is traditionally taken as four, eight or twenty. Concentration ratio is not taking into consideration all firms which are active in industry; furthermore, it is not giving information about the relationship between relative strength's division among the group of big firms and the other industry firms. Also, concentration ratio does not indicate if the largest companies are always the same large companies or not. Thus this index cannot explain the growth variances of the industry. Additionally since a certain subjectivity is an issue at some stages of the index calculation; concentration ratio is characterized as a permissive measure. In the studies carried out to eliminate this subjectivity, $50 \%$ concentration of the four-firm concentration ratio corresponds to the $70 \%$ of the eight-firm concentration ratio. Therefore for four-firm analysis $50-55 \%$ and for eight-firm analysis $70 \%$ concentration levels are accepted as the base points (Tekeli et al., 1980, p. 22).

A low concentration ratio indicates a greater degree of competition whereas high concentration ratio indicates a lesser degree of competition. In a monopolistic market, concentration ratio is $100 \%$ (Parkin, 2005, p. 206). Concentration ratios that are accounted by using market coverage rates indicated by Turkish Statistical Institute (TurkStat) according to the sales revenues, encapsulate the totality of the state sector in manufacturing industry and companies with 10 or more employees in private sector.

Concentration ratios in Turkish manufacturing industry are reviewed in four sections according to the concentration ratio $\mathrm{CR}_{4}$ as if the value is in between 0-30 then low degree (there is competition), in between 31-50 middle degree (competition decreases and oligopolistic structure starts to emerge), in between 51-70 high degree (competition decreases immensely and oligopolistic structure emerges) and in between 71-100 very high degree concentration (monopolistic structure emerges) (www.tuik.gov.tr).

Concentration ratio is used basically for two purposes. First of all it is used to measure the market coverage ratios of several largest companies which manufacture a special product in a private sector (i.e. oligopolistic market). The second purpose is to measure the degree of oligopoly of the largest companies (Adelman, 1951, p. 271).

\subsection{Herfindahl-Hirschman Index}

Another measure to account the concentration is the Herfindahl-Hirschman index. Developed by Hirschman in 1945 and rearranged by Herfindahl, Herfindahl-Hirschman index is defined as the square sums of the shares of the companies in the industry. Herfindahl-Hirschman index is assessed as an indicator of the sizes of both companies and the competitions between them in the industry. Herfindahl-Hirschman index can be formulized as follows (Pepall et al., 2005, p. 49).

$$
H H=\sum_{i=1}^{N} P_{i}^{2}
$$

Where $\mathrm{N}$ is the number of the companies in the industry and $\mathrm{P}_{\mathrm{i}}^{2}$ is the square of the market share of the $\mathrm{i}_{\text {th }}$ company, then the largest value of the Herfindahl-Hirschman index is 1 whereas the lowest value is $1 / \mathrm{N}$. Index takes its values in between 0 and 1. As index value approaches to 1 concentration increases. Index value decreases by the increases in $\mathrm{N}$ and increases by the decreases in $\mathrm{N}$. High value of the index indicates a lesser competition in the concerning industry (Martin, 1988, p. 102). Differently from the concentration ratio, this index takes all company distributions into account. 
Market structures can be defined as perfectly competitive with Herfindahl-Hirschman index smaller than 1000, monopolistic competitive with the index in between 1000-1800, and non-competitive with an index value bigger than 1800 (Parkin, 2005, p. 207).

One of the important inconveniences of the Herfindahl-Hirschman index usage is the need for the market share ratios of the all companies operating in the market. Any data not included in the index may result inaccurate measurements (Weinstock, 1982, pp. 185-301).

\subsection{Entropy Index}

Assuming $\mathrm{N}$ is the number of the companies in the industry and $\mathrm{P}_{\mathrm{i}}$ is the market share of the $\mathrm{i}_{\text {th }}$ company, then Entropy Index can be formulized as follows (Jacquemin \& Berry, 1979, p. 360).

$$
E=\sum_{i=1}^{N} P_{i} \ln \frac{1}{P_{i}}
$$

Entropy index takes values between 0 and $\log \mathrm{N}$. Low value of the index is an indication of a high concentration value. If there is only one company in the industry (monopolistic) the value of the index shall be zero and the concentration degree shall be maximum. As E index approaches to 1 concentration degree shall be decreased (Barthwall, 2004, p. 197).

Economists could not agree on a common opinion about the best concentration index. Each of the concentration measures has its advantages and disadvantages comparing one to the other. If an industry takes its form by the leadership of a few companies then N-Firm concentration ratio might be used as an efficient measure. On the other hand, if small companies have big activities in the industry as well, then $\mathrm{H}-\mathrm{H}$ index might be more efficient for measuring the concentration (Yildırım et al., 2005, p. 46).

\section{Summary of Data and Literature}

It is possible to run across plenty of national and international studies about measurements of concentration in the literature. Below there are some of the studies carried out nationally or internationally:

Rosenbluth (1957) tried to determine concentration levels for 96 sectors in Canadian Manufacturing Industry by the help of Concentration Ratio and Herfindahl-Hirschman Index by using the data of the year of 1948; and then he compared concentration levels of Canadian Manufacturing Industry and American Manufacturing Industry. The research has revealed that despite of varying concentration levels of different sectors in Canadian Manufacturing Industry, the concentration levels determined to be high.

Shepherd (1961), by using the data of the year 1957 and help of $C R_{3}$ and $C R_{4}$ concentration ratio values predicted and compared the concentration levels of American and English Manufacturing Industries. As a result of the research concentration levels accounted for American Manufacturing Industry in general and on the sector basis were found to be higher than the concentration levels of English Manufacturing Industry.

Sands (1962) analyzed concentration levels in American Manufacturing Industry for 47 sectors by using CR index for the 1904-1947 years period. As a result of the research, concentration levels of 28 sectors were found to be increasing; and concentration levels of the other 19 sectors were found to be decreasing or unchanging for the concerning period.

Shepherd (1964) determined concentration levels in the American Manufacturing Industry by using $C R_{4}, C R_{8}$ and $C R_{20}$ index values for the 1947-1958 years period. The research yielded an increase in the concentration levels in general for the concerning period.

Pashigian (1968) determined the concentration levels of English and American Manufacturing Industries with the data of the year 1951 and by using Concentration Ratios; then compared manufacturing industries of these two countries. The research concluded that the concentration level accounted for English Manufacturing Industry has been higher than the concentration level accounted for American Manufacturing Industry.

Bain (1970) analyzed the variations of $C R_{4}$ concentration ratio of the American Manufacturing Industry in 1954-1966 period. The research concluded that during 1954 and 1966 period the concentration levels in the American Manufacturing Industry showed an upward tendency which had a mid-level trend.

Sawyer (1971), by utilizing the data of the 1958-1963 years period and using $C R_{4}, C R_{8}, C R_{12}, C R_{20}$, Gini Ratio and Herfindahl-Hirschman Index tried to determine the concentration levels of the English Manufacturing Industry. As a result of the research the concentration levels of the English Manufacturing Industry was found to have an upward tendency in the concerning years.

Rotwein (1976) tried to determine the concentration levels of 11 industries in the Japanese Manufacturing 
Industry in the 1956-1970 years period. The study revealed a gradual increase in the concentration levels in the concerning period.

Cortes (1998) by the data of 1983-1992 years period and using $C R_{4}, C R_{10}$ and Herfindahl-Hirschman Index values analyzed the concentration levels for 436 sectors in the Japanese economy. The research concluded that during the corresponding time period Japanese Economy has been highly dominated by the companies having oligopolistic structures.

Pryor (2002) accounted concentration levels of the American Manufacturing Industry by utilizing $C R_{4}$ and $C R_{8}$ index values and then compared these ratios with each other in the years of 1992 and 1997 . The study revealed a gradual increase of the concentration levels of the retail trade sector.

Matthes and et al. (2007) tried to determine the concentration levels of the Electrical Markets throughout 6 different regions in Europe for 1996-2005 years period by utilizing the Concentration Ratio and Herfindahl-Hirschman Index. The research revealed that in England and Scandinavian regions market structures have not been concentrated but in the other regions, due to the state dominated monopoly concentrations have found to be in the critical trends.

American Bureau of Statistics has calculated concentration ratios for the largest 4, 8, 20 and 50 companies in the American Manufacturing Industry in their report entitled "Concentration Ratios in Manufacturing" and prepared in 1997 and 2002. In the report the concentration level has been stated to have an upward tendency.

American Federal Trade Commission tried to determine the concentration levels in the ethanol market by utilizing the Herfindahl-Hirschman Index in the reports they prepared in the years of 2005, 2006, 2007, 2008 and 2009. Reports revealed that ethanol market has not been concentrated.

Fedderke and Szalontai (2009) accounted concentration levels of South African Manufacturing Industry by using Rosenbluth Index and Gini Index for the 1972-1996 years period. In the research concentration level appeared to be gradually increasing during the concerning time period.

Erlat (1976) analyzed concentration level in Turkish Manufacturing Industry with the data of the years 1963 and 1969 and by utilizing the Concentration Ratio, Herfindahl-Hirschman Index, Rosenbluth Index and Entropy Index values and compared these four indices. In the research $C R_{4}$ Index has calculated to have the greatest value among these four indices whereas the Entropy Index to have the lowest one.

Tekeli and et al. (1980) determined the concentration levels of 126 sectors in the Turkish Manufacturing Industry by using Concentration Ratio, Herfindahl-Hirschman Index, Entropy of the Distribution, Coefficient of Variation and Linda Index values by utilizing the data provided in the annual Manufacturing Industry Survey published by the State Institute of Statistics in 1976. In the research, considering the data of the year 1976 the oligopolistic territory in the Turkish Manufacturing Industry has been stated to be quite narrow.

Yildirım (1988) tried to determine the concentration levels of 86 sectors in the Turkish Manufacturing Industry by using Gini Index and utilizing the data provided in the annual Manufacturing Industry Survey published by the State Institute of Statistics in 1984. In the research concentration ratios calculated as bigger than $51 \%$ for the 33 of the sectors, and in between $40 \%-50 \%$ for the 22 of the sectors among the concerning 86 sectors.

Özhan (1990) determined the concentration level in the Turkish Manufacturing Industry by using $\mathrm{CR}_{2}, \mathrm{CR}_{4}$ and $\mathrm{CR}_{8}$ Index values and defined the factors designating the concentration levels. The research revealed that four-firm concentration ratio of the $1 / 3$ of the sectors in the manufacturing industry has been higher than $80 \%$.

Kaytaz and et al. (1993) determined the concentration level in the Turkish Manufacturing Industry by using concentration ratio and Herfindahl-Hirschman Index for 1989-1990 years period. In the research according to $\mathrm{CR}_{4}$ and Herfindahl-Hirschman Index sectors having the highest concentrations found to be yarn, string, net, rope industry not elsewhere classified weaving products industry and fur processing industry.

Özmucur (1997) tried to correct the concentration ratios $\left(\mathrm{CR}_{4}, \mathrm{CR}_{8}\right.$ and Herfindahl-Hirschman Index) published by the State Institute of Statistics (SIS) for the 1985-1989 years period. The research emphasized the need for applying the correction factor on the concentration indices which published by the SIS.

State Institute of Statistics tried to determine the concentration level in the Turkish Manufacturing Industry by using Concentration Ratio and Herfindahl-Hirschman Index for 1980-1994 years period. According to the study meanwhile $\mathrm{CR}_{4}$ has been $55.6 \%$ in average and $\mathrm{CR}_{8}$ has been $66.2 \%$ in average, the value of $\mathrm{CR}_{4}$ has found to be $50.4 \%$ and $\mathrm{CR}_{8}$ has found to be $58.8 \%$ when calculated according to the weighted sales revenues in between the years of 1980-1994. Also the most competitive sectors determined to be the ready-made clothing, fiber yarn, weaving, dying, knitting, flour and bakery products; whereas the highest monopolistic sectors determined to be 
yarn, string and rope industry, packaging industry, bituminous based construction, insulation and binding materials productions, railway transportation vehicles manufacturing, all kinds of sports, athletics, gymnastics tools manufacturing, petroleum refineries, inner and outer rubber tire production, motorcycle, bicycle manufacturing and repairing, internal combustion engines and tribune industry, mineral oil preparation and blending processes.

Kazan and Atan (1999) determined the concentration levels of 26 manufacturing sectors by using $\mathrm{CR}_{4}, \mathrm{CR}_{8}$, Herfindahl-Hirschman, Entropy and Linda Index values and by utilizing the sales revenue data of the 500 big companies of Turkey in 1997. The research revealed that $65.4 \%$ of the total sectors have had the concentration ratios higher than the critical point value which has been $50 \%$.

Erlat and Akyüz (2001) analyzed import and export concentration levels of Turkey by using $\mathrm{CR}_{4}$, Herfindahl-Hirschman Index, Rosenbluth-Hall-Tideman, Comprehensive Concentration Index and Entropy Index values and compared these indices with each other. The study showed that $C R_{4}$ index has taken the highest value whereas Herfindahl-Hirschman Index has taken the lowest.

Akan (2002) worked to determine the concentration levels in the Turkish Manufacturing Industry for 1980-1996 years period. The research concluded that more than the half of the Turkish Manufacturing Industry has been dominated by the oligopolistic companies.

Baş (2004) interpreted concentration levels of Turkish Manufacturing Industry which have been calculated by $\mathrm{CR}_{4}$ Index for 1980-2001 years period. The research resulted high concentration levels for the most of the big sectors which establish the foundations of the economy.

Kulaksizoğlu (2004) analyzed concentration level of Turkish Cement Sector by considering the production rates and by utilizing $\mathrm{CR}_{4}, \mathrm{CR}_{8}$, Herfindahl-Hirschman Index values for the 1978-2002 years period. According to the research, from the beginning to the end of the concerning time period concentration has determined to be increasing.

Eser and Köse (2005) analyzed industries in the cities by determining concentration levels of 12 sub-sectors for 44 cities in Turkey by using data of the year 2000 and by utilizing Herfindahl-Hirschman Index. The research revealed that according to the fundamental industrial indicators such as the number of the companies, employment, added value and export, concentration levels have been high in the traditional industry centers like İstanbul, Ankara, İzmir, Adana, Bursa, Kocaeli.

Polat (2007) tried to determine the market structure of the cement sector in Turkey by utilizing $\mathrm{CR}_{4}, \mathrm{CR}_{8}$ and Herfindahl-Hirschman Index values for the years of 2001-2005. In the research Turkish Cement Sector determined to be standing on the border of the monopolistic competitive and oligopolistic market according to the concentration ratio analysis whereas having more competitive market structure according to the Herfindahl-Hirschman analysis.

Yolaç (2007) researched the factors effecting concentration levels for 84 sub-sectors in Turkish Manufacturing Industry for the year 2000. The research concluded that the scale economies and advertisement costs had an important role on determining the concentration.

Durukan and Hamurcu (2009) tried to determine the market structures and concentration ratios by using Herfindahl-Hirschman Index in the mobile communication markets in Turkey and 5 other countries in Central Asia Turkic Republics for the 2002-2007 years period. The research revealed that Turkey, Kazakhstan, Kirghizstan and Turkmenistan had non-competitive over-concentrated oligopolistic market structures whereas Tajikistan and Uzbekistan had middle degree concentrated oligopolistic market structures.

Baysal and Çavuşoğlu (2009) tried to determine the concentration level of Turkish Manufacturing Industry by using data of the year 2001. According to the research concentration ratios of the manufacturing industry determined to be high and a clear majority of the companies in the manufacturing industry operated in oligopolistic structures.

Kaynak and Ari (2011) reviewed concentration levels of Turkish Automotive Industry by utilizing N-Firm Concentration Ratios $\left(\mathrm{CR}_{4}\right.$ and $\left.\mathrm{CR}_{8}\right)$ and Herfindahl-Hirschman index values in the 2003-2010 years period. The research concluded that according to $\mathrm{CR}_{4}$ domestic automobile and domestic light commercial vehicle sectors and according to $\mathrm{CR}_{8}$ imported light commercial vehicle sector had high levels of concentrations. According to Herfindahl-Hirschman index domestic light commercial vehicle and automobile sectors had monopolistic competitive market structures whereas imported automobile and light commercial vehicle sectors had low concentration ratios and consequently had more competitive structures. 
Güven and Yeni (2013) determined the relations among concentration, profitability and wages in Turkish Manufacturing Industry for the 1985-2001 years period. The research reported a positive relation among concentration, profitability and wages.

Pehlivanoğlu and Tiftikçigil (2013) examined concentration levels in Turkish Iron-Steel and Metal Industries by utilizing $\mathrm{CR}_{4}, \mathrm{CR}_{8}, \mathrm{CR}_{12}$ and Herfindahl-Hirschman index values for the 1995-2001 years period. The research reported a monopolistic competitive structure according to $\mathrm{CR}_{4}$ and oligopolistic market structure according to $\mathrm{CR}_{12}$ for the concerning industries.

Akardeniz and Kıraç (2015) analyzed concentration levels of the companies operated in the field of non-woven in the technical textiles sector in Gaziantep by using N-Firm Concentration Ratio and Herfindahl-Hirschman Index values in the year of 2013. The study showed that the sector had an oligopolistic market structure.

Measures utilized for calculating the concentration which is assessed to measure the market structure, generally are employment, sales, fixed assets, added-value, etc. In this study as for the concentration measures domestic sales, non-domestic sales and net sales variables are used and concentration level of the Turkish Cement Industry is analyzed by using $\mathrm{CR}_{4}, \mathrm{CR}_{8}$, Herfindahl-Hirschman and Entropy Index values.

In this study the data used to calculate the concentration for 2010-2014 years period are gathered from the annual accounts and annual activity reports of the companies which are the members of the Turkish Cement Manufacturer's Association.

\section{Empirical Evidence}

In this section calculated values of $\mathrm{CR}_{4}, \mathrm{CR}_{8}$, Herfindahl-Hirschman Index and Entropy Index of the Turkish Cement Industry for the 2010-2014 years period and interpretations of the indices are evaluated.

\subsection{Market Structure of Turkish Cement Industry According to N-Firm Concentration Ratio}

$\mathrm{CR}_{4}$ index which is calculated according to domestic, non-domestic and net sales variables for 2010-2014 years period is shown in Table 5 .

Table 5. $\mathrm{CR}_{4}$ Index (\%)

\begin{tabular}{cccc}
\hline Years & $\begin{array}{c}\mathbf{C R}_{\mathbf{4}} \\
\text { (Domestic Sales) }\end{array}$ & $\begin{array}{c}\mathbf{C R}_{\mathbf{4}} \\
\text { (Non-Domestic Sales) }\end{array}$ & $\begin{array}{c}\mathbf{C R}_{\mathbf{4}} \\
\text { (Net Sales) }\end{array}$ \\
\hline $\mathbf{2 0 1 0}$ & 50,6 & 60,7 & 50,7 \\
$\mathbf{2 0 1 1}$ & 51,7 & 63,9 & 53,3 \\
$\mathbf{2 0 1 2}$ & 51,4 & 71,4 & 51,9 \\
$\mathbf{2 0 1 3}$ & 51,1 & 65,5 & 50,4 \\
$\mathbf{2 0 1 4}$ & 50,2 & 64,9 & 50,1 \\
\hline
\end{tabular}

Source: Authors own calculation

As can be seen in the Table $5, \mathrm{CR}_{4}$ index calculated according to domestic sales variables is taken values in between $50,2 \%$ and $52,7 \%$. If we examine this situation by considering the Turkish Statistical Institute's criteria, then we can conclude that the industry concentrates highly and cement industry has an oligopolistic market structure according to the domestic sales variable; and also because the values are close to the upper level of $50 \%$ it is possible to state that the oligopolistic structure indicates a weak structure.

On the other hand, $\mathrm{CR}_{4}$ index values calculated on non-domestic sales variable basis varies in between $60,7 \%$ and $71,4 \%$. With regard to these values it can be concluded that the competition in the cement industry is decreased significantly and therefore the industry can be considered to have a strong oligopolistic market characteristics. Also, $\mathrm{CR}_{4}$ index values calculated on net sales variable basis resides in between $50,1 \%$ and $53,3 \%$. In the light of these values it can be stated that competition in the cement industry is decreased and the industry sets an example of a weak oligopolistic market structure.

$\mathrm{CR}_{8}$ index values determined according to domestic, non-domestic and net sales variables for the concerning time period are shown in Table 6. 
Table 6. $\mathrm{CR}_{8}$ Index (\%)

\begin{tabular}{cccc}
\hline Years & $\begin{array}{c}\mathbf{C R}_{\mathbf{8}} \\
\text { (Domestic Sales) }\end{array}$ & $\begin{array}{c}\mathbf{C R}_{\mathbf{8}} \\
\text { (Non-Domestic Sales) }\end{array}$ & $\begin{array}{c}\mathbf{C R}_{\mathbf{8}} \\
\text { (Net Sales) }\end{array}$ \\
\hline $\mathbf{2 0 1 0}$ & 74,9 & 87,9 & 73,8 \\
$\mathbf{2 0 1 1}$ & 73,9 & 91,0 & 75,1 \\
$\mathbf{2 0 1 2}$ & 72,7 & 93,3 & 73,2 \\
$\mathbf{2 0 1 3}$ & 75,1 & 91,8 & 74,8 \\
$\mathbf{2 0 1 4}$ & 73,8 & 92,4 & 73,7 \\
\hline
\end{tabular}

Source: Authors own calculation

When Table 6 is examined then it can be seen that $\mathrm{CR}_{8}$ index is calculated according to the domestic sales variable, takes values in between $72,7 \%$ and $75,1 \%$. Since the level of $50 \%$ of the $\mathrm{CR}_{4}$ ratio corresponds to the $70 \%$ of the $\mathrm{CR}_{8}$ ratio, in the concerning time period and according to the domestic sales variable it can be concluded that the industry is highly concentrated and the cement industry carries the characteristics of an oligopolistic market structure; also because the values are close to the upper level of $70 \%$ it is possible to state that they define a weak oligopolistic structure.

$\mathrm{CR}_{8}$ index values are calculated on non-domestic sales variable basis reside in between $87,9 \%$ and $93,3 \%$. According to these values it can be stated that competition in the cement industry is decreased significantly and the industry exhibits a strong oligopolistic market structure

Also, $\mathrm{CR}_{8}$ index values are calculated according to the net sales variable lies in between $73,2 \%$ and $75,1 \%$. Therefore it can be stated that competition in the cement industry is decreased and the industry sets an example of a weak oligopolistic market structure.

\subsection{Market Structure of the Turkish Cement Industry According to H-H Index}

Herfindahl-Hirschman index values calculated according to domestic, non-domestic and net sales variables for the 2010-2014 years period are shown in Table 7.

Table 7. Herfindahl-Hirschman Index

\begin{tabular}{cccc}
\hline Years & $\begin{array}{c}\text { HH } \\
\text { (Domestic Sales) }\end{array}$ & $\begin{array}{c}\text { HH } \\
\text { (Non-Domestic Sales) }\end{array}$ & $\begin{array}{c}\text { HH } \\
\text { (Net Sales) }\end{array}$ \\
\hline $\mathbf{2 0 1 0}$ & 897,6 & 1211,3 & 860,1 \\
$\mathbf{2 0 1 1}$ & 902,8 & 1357,4 & 928,8 \\
$\mathbf{2 0 1 2}$ & 896,0 & 1609,6 & 893,6 \\
$\mathbf{2 0 1 3}$ & 902,5 & 1460,1 & 863,4 \\
$\mathbf{2 0 1 4}$ & 891,2 & 1526,7 & 844,2 \\
\hline
\end{tabular}

Source: Authors own calculation

When Table 7 is examined it can be seen that Herfindahl-Hirschman index calculated according to the domestic sales variable takes values in between 891,2 and 902,8 . This situation different than the $\mathrm{CR}_{4}$ and $\mathrm{CR}_{8}$ analysis indicates a more competitive structure of the cement industry due to the calculated values that are less than 1000 .

Herfindahl-Hirschman index values calculated according to non-domestic sales variable reside in between 1211,3 and 1609,6. According to these values it can be stated that the cement industry has the characteristics of a monopolistic competitive market structure.

Also Herfindahl-Hirschman index values calculated according to net sales variable are in between 844,2 and 928,8 . These values indicate that the cement industry sets an example of a competitive market structure.

\subsection{Market Structure of the Turkish Cement Industry According to Entropy Index}

Entropy index values which are calculated according to domestic, non-domestic and net sales variables for the 2010-2014 years period are shown in Table 8 . 
Table 8. Entropy Index

\begin{tabular}{cccc}
\hline Years & $\begin{array}{c}\mathbf{E} \\
\text { (Domestic Sales) }\end{array}$ & $\begin{array}{c}\mathbf{E} \\
\text { (Non-Domestic Sales) }\end{array}$ & $\begin{array}{c}\mathbf{E} \\
\text { (Net Sales) }\end{array}$ \\
\hline $\mathbf{2 0 1 0}$ & 0,88 & 0,78 & 0,90 \\
$\mathbf{2 0 1 1}$ & 0,88 & 0,76 & 0,88 \\
$\mathbf{2 0 1 2}$ & 0,89 & 0,71 & 0,89 \\
$\mathbf{2 0 1 3}$ & 0,88 & 0,74 & 0,89 \\
$\mathbf{2 0 1 4}$ & 0,89 & 0,72 & 0,90 \\
\hline
\end{tabular}

Source: Authors own calculation

When Table 8 is examined it can be seen that Entropy index calculated according to domestic sales variable takes values in between 0,88 and 0,89 ; Entropy index calculated according to according to non-domestic variable takes values in between 0,71 and 0,78; and Entropy index calculated according to net sales variable takes values in between 0,88 and 0,90 . Since the index values are close to 1 this situation indicates that the concentration is low and therefore the cement industry has a competitive structure with regard to these three variables.

\section{Discussion}

Considering the provided manufacturing, employment and export rates, cement industry occupies a strategically important leading sector position in Turkey.

In this study the concentration level is analyzed for the 2010-2014 years period by utilizing $\mathrm{CR}_{4}, \mathrm{CR}_{8}$, Herfindahl-Hirschman and Entropy index values calculated according to the domestic, non-domestic and net sales variables gathered from the annual accounts and annual activity reports of the companies which are the members of Turkish Cement Manufacturer's Association and operating in the Turkish Cement Industry.

As a result of $\mathrm{CR}_{4}$ and $\mathrm{CR}_{8}$ analysis carried out in this study, the industry is determined to be a weak oligopolistic example according to the domestic and net sales variables whereas according to the non-domestic sales variable the industry is determined to have a strong oligopolistic market structure. Thus it is possible to state that the industry concentrates more with regard to export.

Also in the light of Herfindahl-Hirschman and Entropy Index values it can be stated that the industry has a competitive market structure. When the concerning index values are compared to each other it is concluded that the companies in the industry concentrate more on the export articles according to the domestic and net sales and so the competition is lesser.

\section{References}

Adelman, M. A. (1951). The measurement of industrial concentration. The Review of Economics and Statistics, 33(4), 269-296.

Akan, Y. (2002). Concentration in turkish manufacturing industry: 1980-96. Ataturk University Journal of Economics and Administrative Sciences, 16(5-6), 1-13.

Akardeniz, E., \& Kıraç, F. (2015). Competition and concentration level's measurement; technical textilles market of gaziantep. The Journal of Academic Social Science, 3(10), 451-472.

Bain, J. S. (1949). Price and production policies. In H. S. Ellis (Ed.), A Survey of Contemporary Economics (pp. 129-173). Philedelphia, The Blackiston Company.

Bain, J. S. (1954). Economies of scale, concentration and the condition of entry in twenty manufacturing industries. American Economic Review, 44, 15-39.

Bain, J. S. (1959). Industrial organization. New York: John Wiley \& Sons Inc.

Bain, J. S. (1970). Changes in concentration in manufacturing industries in the united states, 1954-1966: Trends and relationships to the levels of 1954 concentration. The Review of Economics and Statistics, 52(4), 411-416.

Barthwall, R. R. (2004). Industrial economics: An introductory textbook. New Delphi: New Age International Publisher.

Baş, M. (2004). Market concentration as a factor affecting competition and reflections on the extent to which 
some sectors in turkey are concentrated. Gazi University Journal of Commerce \& Tourism Education Faculty, 2, 109-119.

Baysal, B., \& Çavuşoğlu, N. (2009). Concentration and competition in Turkish manufacturing industry. Finans, Politik \& Ekonomik Yorumlar, 46(528), 39-52.

Cortes, B. S. (1998). Trends in industrial concentration in japan, 1983-92. International Review of Applied Economics, 12(2), 271-281.

Curry, B., \& George, K. D. (1983). Industrial concentration: A survey. The Journal of Industrial Economics, 31(3), 203-255.

Durukan, T., \& Hamurcu, Ç. (2009). Market condensation in mobile communications. Journal of Black Sea Studies, 6(22), 75-86.

Erlat, G. (1976). A comparison of four measures of industrial concentration within the context of the turkish manufacturing industry. METU Studies in Development, 10, 43-73.

Erlat, G., \& Akyüz, O. (2001). Country concentration of turkish exports and imports over time. Topics in Middle Eastern and North African Economies, 3.

Eser, U., \& Köse, S. (2005). Industrial localization and concentration in the turkish industry: An analysis of manufacturing industries in provinces. Ankara University The Journal of the Faculty of Political Sciences, 60(2), 97-139.

Fedderke, J., \& Szalontai, G. (2009). Industry concentration in south african manufacturing industry: Trends and consequences, 1972-1996. Economic Modelling, 26, 241-250.

FTC. (2009). Report on ethanol market concentration. Retrieved from http://www.ftc.gov/os/2009/12/ 091201 ethanolreport.pdf

Güven, A., \& Yeni, O. (2013). The Relationship between concentration, profitability, and wages in turkey's manufacturing industries: Reconsidered. Hacettepe University Journal of Economics and Administrative Sciences, 31(2), 95-115.

Hall, R. E. (1988). The relation between price and marginal cost in U.S. industry. Journal of Political Economy, 96, 921-947.

Jacquemin, A. P., \& Berry, C. H. (1979). Entropy measure of diversification and corporate growth. The Journal of Industrial Economics, 27(4), 359-369.

Kaynak, S., \& Ari, Y. O. (2011). Concentration in Turkish automotive sector: An application on passenger and light commercial vehicles. Ekonomik Yaklasim Journal, 22(80), 39-58. http://dx.doi.org/10.5455/ey.20023

Kaytaz, M., Altın, S., \& Güneş, M. (1993). Concentration in turkish manufacturing industry/1990. TMMOB Bildiriler Kitabl, 1, 49-59. Retrieved from http://arsiv.mmo.org.tr/ pdf/10104.pdf

Kulaksızoğlu, T. (2004). Measuring the effectiveness of competition policy: Evidence from the turkish cement industry. Retrieved from http://mpra.ub.unimuenchen.de/357/01/MPRA_paper_357.pdf

Martin, S. (1988). Industrial economics: Economic analysis and public policy. New York: MacMillan Publishing Company.

Mason, E. S. (1939). Price and production policies of large-scale enterprise. American Economic Review, 29, 61-74.

Matthes, F. C., Grashof, K., \& Gores, S. (2007). Power generation market concentration in Europe 1996-2005: An empirical analysis. Retrieved from www.greensefa.org/cms/default/dokbin/168/168183.oko_institut_en ergy_market_liberalisatio en.pdf

Özhan, M. (1990). 1988 yılında türk imalat sanayiinde yoğunlaşma düzeyi ve bu düzeyi belirleyen faktörler. Hacettepe Üniversitesi İktisadi ve İdari Bilimler Fakültesi Dergisi, 8(2), 105-116.

Özmucur, S. (1997). Concentration in manufacturing industry. METU Studies in Development, 24(4), 509-518.

Parkin, M. (2005). Microeconomics. Boston: Pearson Addison Wesley.

Pashigian, B. P. (1968). Market concentration in the united states and great britain. Journal of Law and Economics, 11(2), 299-319.

Pashigian, B. P. (1969). The effect of market size on concentration. International Economic Review, 10, 291-314. 
Pehlivanoğlu, F., \& Tiftikçigil, B. Y. (2013). A concentration analysis in the turkish iron-steel and metal industry. International Journal of Economic Practices and Theories, 3(3), 152-167.

Pepall, L., Richards, D. J., \& Norman, G. (2005). Industrial organization contemporary theory\&practice. Canada, Thomson South Western.

Polat, Ç. (2007). Structural analysis of turkish cement sector within context of concentration and market structure relation. Anadolu University Journal of Social Sciences, 7(2), 97-116.

Pryor, F. L. (2002). News from the monopoly front: Changes in industrial concentration, 1992-1997. Review of Industrial Organization, 20, 183-185.

Rosenbluth, G. (1957). Concentration in canadian manufacturing industries. Princeton: Princeton University Press.

Rotwein, E. (1976). Economic concentration and monopoly in japan-a second view. The Journal of Asian Studies, 36(1), 57-77.

Sands, S. S. (1962). Concentration in United States manufacturing industry, 1904-1947. International Economic Review, 3(1), 79-93.

Sawyer, M. C. (1971). Concentration in British manufacturing industry. Oxford Economic Papers, 23, 352-358.

Shepherd, W. G. (1961). A comparison of industrial concentration in the United States and Britain. The Review of Economics and Statistics, 43(1), 70-75.

Shepherd, W. G. (1964). Trends of concentration in American manufacturing industries. The Review of Economics and Statistics, XLVI(2), 200-212.

Shepherd, W. G. (1972). Trends structure and behaviour in British industries with U. S. comparisons. Journal of Industrial Economics, XXI(1), 35-54.

Su, K. T. (2003). Rekabet hukukunda teşebbüslerin hakim durumunun belirlenmesinde pazar gücünün ölçülmesi. Ankara, Rekabet Kurumu.

Tekeli, İ., İlkin, S., Aksoy, A., \& Kepenek, Y. (1980). Türkiye'de sanayi kesiminde yoğunlaşma. Ankara, ODTÜ Sosyal Araştırma Enstitüsü.

Waldman, D. E., \& Jensen, E. J. (2001). Industrial organization: Theory \& Practice. Boston: Pearson Addison Wesley.

Weinstock, D. S. (1982). Using the herfindahl index to measure concentration. The Antitrust Bulletin, 27(2), 285-301.

www.tcma.org.tr.

www.tüik.gov.tr.

Yıldırım, E. (1988). Türkiye imalat sanayiinde ekonomik yoğunlaşmanın ölçülmesi. Çukurova Üniversitesi İIBF Dergisi, 2(1), 89-103.

Yıldırım, K., Eşkinat, R., \& Kabasakal, A. (2005). Endüstriyel ekonomi. Bursa: Ekin Kitabevi.

Yolaç, S. (2007). Concentration in turkish manufacturing industry. Journal of Social Policy Conferences, 50, 1087-1100.

\section{Copyrights}

Copyright for this article is retained by the author(s), with first publication rights granted to the journal.

This is an open-access article distributed under the terms and conditions of the Creative Commons Attribution license (http://creativecommons.org/licenses/by/3.0/). 